\title{
Study of the Effect of Lampeni (Ardisia humilis Vahl.) Planting Condition toward the Alpha-glucosidase Inhibition Activity In vitro
}

\author{
Sri Ningsih ${ }^{1, *}$, Fifit Juniarti ${ }^{1}$, Idah Rosidah ${ }^{1}$, Adam Arditya Fajriawan ${ }^{1}$, Kurnia Agustini ${ }^{1}$, Syofi Rosmalawati ${ }^{2}$, \\ Agung Eru Wibowo ${ }^{2}$, Erliana Sasikirana ${ }^{3}$, Wahono Sumaryono ${ }^{3}$
}

Sri Ningsih",*, Fifit Juniarti', Idah Rosidah ${ }^{1}$, Adam Arditya Fajriawan', Kurnia Agustini', Syofi Rosmalawati ${ }^{2}$, Agung Eru Wibowo $^{2}$, Erliana Sasikirana ${ }^{3}$, Wahono Sumaryono ${ }^{3}$

'Center for Pharmaceutical and Medical Technology, Agency for the Assessment and Application of Technology. Laptiab building, Puspiptek Serpong Area, South Tangerang, Banten, INDONESIA.

'Laboratory of Biotechnology, Agency for the Assessment and Application of Technology, Puspiptek Serpong Area, South Tangerang, INDONESIA.

${ }^{3}$ Faculty of Pharmacy, Pancasila University. Srengseng Sawah Street, South Jakarta, INDONESIA.

\section{Correspondence}

Sri Ningsih

Center for Pharmaceutical and Medical Technology, Agency for the Assessment and Application of Technology. Laptiab building, Puspiptek Serpong Area, South Tangerang, Banten, INDONESIA.

E-mail: Sri.ningsih@bppt.go.id

History

- Submission Date: 30-12-2019;

- Review completed: 07-01-2020;

- Accepted Date: 16-01-2020.

DOI : 10.5530/pj.2020.12.59

Article Available online http://www.phcogj.com/v12/i2

\section{Copyright}

(C) 2020 Phcogj.Com. This is an openaccess article distributed under the terms of the Creative Commons Attribution 4.0 International license.

\begin{abstract}
Background: The quality of a medicinal plant is influenced by agronomic conditions and harvesting time. Objective: This study aimed to evaluate the effect of planting method (openair (OA) and shedding house (SH)) and harvesting time (2, 4, 6 months) of Lampeni (Ardisia humilis Vahl.) toward the inhibitory activity of alpha-glucosidase. Methods: The Lampeni seedling were placed under controlled light conditions $(\mathrm{SH})$ and on direct sun exposure (OA). Harvesting of the leaves was carried out at the age of 2, 4, and 6 months after plantation $(2 \mathrm{~m}, 4 \mathrm{~m}$, and $6 \mathrm{~m})$. Each leaves dry powder was refluxed with methanol $70 \%$ and followed by liquid-liquid partition using $n$-hexane, ethyl acetate (EtOAc), and water. All samples were evaluated toward inhibition of the alpha-glucosidase enzyme in vitro. Total phenol levels were determined using Folin-Ciocalteu reagent. Results: The results showed that EtOAc fractions of both plantation techniques exhibited the highest inhibition of alpha-glucosidase. The highest activity was demonstrated by the $4 \mathrm{~m}-\mathrm{OA}-\mathrm{EtOAc}$ fraction $\left(\mathrm{IC}_{50^{\prime}}, 93.50 \mathrm{ppm}\right)$ and followed by the $6 \mathrm{~m}-\mathrm{OA}-\mathrm{EtOAc}$ fraction $\left(\mathrm{IC}_{50}, 98.13 \mathrm{ppm}\right)$. Based on the kinetic study, the inhibition type of the two most active samples were categorized as a non-competitive type. Total phenolic contents were decreased in the following order: $6 \mathrm{~m}-\mathrm{SH}$-EtOAc $>4 \mathrm{~m}-\mathrm{OA}-\mathrm{EtOAc}>6 \mathrm{~m}-\mathrm{OA}$ EtOAc $>4 m-S H-E t O A c$ fraction. It was shown that there was no positive correlation between the strength of inhibition with total phenolic content. Conclusions: This study concluded that Lampeni at open-air plantation harvested on fourth months demonstrated the highest alpha-glucosidase inhibitory activity, although there was no positive correlation between the inhibition activity and phenolic content.

Key words: Alpha-glucosidase, Ardisia humilis Vahl., Lampeni, Open-air, Shedding house, Total phenolic.
\end{abstract}

\section{INTRODUCTION}

Diabetes mellitus (DM) is a disease characterized by the rise of blood glucose levels beyond normal (hyperglycemia) caused by a defect of insulin production and/or insulin response. Postprandial hyperglycemia is the elevation of plasma glucose after a meal. There were some shreds of evidence that the loss of postprandial glucose control both in DM or non-DM people may be an independent risk factor and could be a potential cause of the cardiovascular disease. ${ }^{1}$ Absorption of starch hydrolysis product is the main source of increased glucose in the blood. A group of enzymes, including pancreatic alpha-amylase and intestinal alpha-glucosidase, are directly involved in starch hydrolysis. Inhibition of these hydrolytic enzymes is believed to be an attempt to control postprandial blood sugar levels. ${ }^{2}$ Conventional DM management using chemical drugs such as biguanides, sulfonylureas, meglitinide, thiazolidinedione (TZD), dipeptidyl peptidase 4 (DPP-4) inhibitors, sodium-glucose cotransporter (SGLT2) inhibitors, and $\alpha$-glucosidase inhibitors are known to cause some side effects. Some evidence of the side effects of synthetic hypoglycemic drugs such as hypoglycemia, digestive, and central nervous system disorders had been reported. ${ }^{3}$ Finally, finding new drugs from natural resources was a strategic effort for solving these problems.

Indonesia is one of the tropical countries that have abundant natural resources from plants, animals, or minerals. Lampeni known as Ardisia humilis Vahl. belongs to Magnoliatae family is a woody plant that is commonly found in the Indonesian forest. This plant had been used as folk medicine with empirical activities such as stimulant, carminative, antidiarrheal, treat rheumatism, skin sore, and vertigo $^{(4)}$ besides as a decorative plant. Previous study reported that the methanolic extract of $A$. humilis demonstrated cytotoxic, thrombolytic, and antioxidant activities. ${ }^{4}$ Mice treated with ethanolic extract of Lampeni at the dose ranged from 100 to $300 \mathrm{mg} / \mathrm{kg}$ bw demonstrated antiplatelet activity by prolonged bleeding time. ${ }^{5}$ Lampeni also has blood glucose-lowering activity in which alpha-amiryn compound was responsible for these biological properties. ${ }^{6}$ The other chemical compound from the other species Ardisia elliptica named beta-amiryn was known for having more potent antiplatelet activity than aspirin.?

Cite this article: Ningsih S, Juniarti F, Rosidah I, Fajriawan AA, Agustini K, Rosmalawati S, et al. Study of the Effect of Lampeni (Ardisia humilis Vahl.) Planting Condition toward the Alphaglucosidase Inhibition Activity In vitro. Pharmacog J. 2020;12(2):377-85. 
It has been a common knowledge that one of the main roles in the production of plant phytochemicals is the growth conditions. The content of chemical compounds in a medicinal plant affects the pharmacological properties. Blum-Silva, et al. ${ }^{8}$ reported that the level of polyphenol and methylxanthine content of Ilex paraguariensis was found higher in the older leaves than the young one and exhibited a difference in the strength of pharmacological activity. Meanwhile, it was also stated that the quantitative analysis of some phytochemical compounds from Ilex paraguariensis were affected by light intensity and the age of the leaves. ${ }^{9}$ Implementation of a good agricultural process (GAP) will produce high quality medicinal plants. ${ }^{10}$ The purpose of this study was to evaluate the effect of agronomic (light intensity and harvesting time) to obtain Lampeni leaves that could demonstrate alpha-glucosidase inhibitory properties. The parameters tested were the light intensity (open-air/direct sun exposure and shedding house) and the harvest time (2, 4, and 6 months).

\section{MATERIAL AND METHODS}

\section{Experimental design}

The scheme of experiments was depicted as in the Figure 1.

\section{Materials}

Chemicals used in this experiment were methanol (Merck), chloroform (Merck), n-hexane (Merck), ethyl acetate (Merck), chloride acid (Merck), aquadest (local market), phosphate buffer solution $\mathrm{pH}$ 7.0 (Merck), p-nitrophenyl- $\alpha-D$-glucopyranoside (Sigma), alphaglucosidase (Sigma), bovine serum albumin (Sigma), dimetyl sulfoxide (Merck), sodium carbonate (Merck), acarbose tablet, folin ciocalteu reagent (Merck), gallic acid (Sigma), toluene (Merck), formic acid (Merck), growing medium consist of soil, sand, compost, Bioroot ${ }^{\oplus}$, Antracol $^{\oplus}$ fungicide (Bayer), Agrept ${ }^{\oplus}$ bactericide, Biopex ${ }^{\oplus}$.

Fully grown 15-20-year-old tree of Lampeni from Ujung Kulon National Park Banten Indonesia was selected as the mother plant. Determination of the plant sample was conducted at LIPI Biology Center, Cibinong, Bogor, Indonesia. Plant seeds were prepared based on the protocol developed by Laboratory of Biotechnology, Agency for The Assessment and Application of Technology. Briefly, the stems containing shoots of the mother plant were cut and soaked in a bactericidal-fungicide solution for 15 minutes and then drained by bloating to tissue paper. Root inductions were carried out by applying Bioroot paste contained hormones at the base of the bottom of the bud. The seedling were then planted in media consisting of the proportionate sand and soil in a polybag. In order to stimulate the shoot growth, the shoots were sprayed with the Biopex hormone solution. Polybags were placed in two conditions, namely, in a shedding house (at a temperature of 25$30 \pm 1^{\circ} \mathrm{C}$ for 16 hours photoperiod and $50-70 \%$ relative humidity) and direct exposure to the sun (open-air, OA) with 45 polybags in each treatment. At this time, the age of leaves was set to zero months. The leaves were collected on 2, 4 and 6 months from each 15 polybags after planting without the top 3-4 leaves, dried under $50^{\circ} \mathrm{C}$ using an oven and then crushed until powder mass obtained for the next process.

\section{Extraction and fractionation process}

The crude extract of each planting method was prepared by reflux technique. Each Lampeni leaves dry powder was refluxed using $70 \%$ methanol for 3 hours. The filtrate was concentrated by a rotary evaporator until semi-solid mass obtained. Toward each semisolid crude extract was added to distilled water and shaken until a homogenous mass obtained. The suspension was then partitioned using $\mathrm{n}$-hexane in a glass separating funnel, followed with ethyl acetate. Each filtrate was concentrated by vacuum evaporator, as stated above. From these extraction processes, there were some samples obtained, namely, a crude extract, $\mathrm{n}$-hexane fraction (Fr.n-hexane), ethyl acetate fraction (Fr.EtOAc), aqueous fraction (Fr.Aquos) of both SH and OA plant that collected at 2,4 , and 6 months.

\section{Alpha-glucosidase inhibitory evaluation in vitro}

Evaluation of alpha-glucosidase inhibitory activity was conducted using p-nitrophenyl-alpha-D-glucopyranoside/alpha-glucosidase system based on the previous study ${ }^{11}$ with modification. Briefly, the enzyme stock solution was prepared by adding $0.125 \mathrm{~g}$ of the intestinal rat $\alpha$-glucosidase enzyme with $5 \mathrm{~mL}$ of a cold phosphate buffer $\mathrm{pH} 7.0$, sonicated and centrifuged at $5000 \mathrm{rpm}, 40^{\circ} \mathrm{C}$ for 5-10 minutes, and then the supernatant was collected into a disposable plastic tube. Enzyme stock was diluted 2.5 times using a phosphate buffer $\mathrm{pH}$ 7.0. The tested samples were prepared by dissolving $20 \mathrm{mg}$ of crude extract/fraction with $200 \mathrm{uL}$ of DMSO homogeneously and diluting with phosphate buffer $\mathrm{pH} 7.0$ to the final concentration of $100 \mathrm{ppm}$. The measurement of alpha-glucosidase inhibition activity was carried out as follow. In the disposable plastic cuvette, $70 \mu \mathrm{L}$ each sample solution, $100 \mu \mathrm{L}$ the p-nitrophenyl-alpha-D-glucopyranoside $10 \mathrm{mM}$, and $80 \mu \mathrm{L}$ phosphate buffer solution $\mathrm{pH} 7.0$ were mixed together and incubated for 5 minutes at $37^{\circ} \mathrm{C}$. The reaction was then started by adding $100 \mu \mathrm{L}$ the enzyme working solution and re-incubated for 15 minutes at $37^{\circ} \mathrm{C}$. The reaction was stopped by adding $400 \mu \mathrm{L} 0.2 \mathrm{M} \mathrm{Na}_{2} \mathrm{CO}_{3}$, and the absorbance was measured at $400 \mathrm{~nm}$ using a UV-Vis spectrophotometer. Sample blank was prepared by replacing the enzyme solution with phosphate buffer pH 7.0. Enzyme control, which states an enzyme without inhibition, was made by replacing the test sample with phosphate buffer $\mathrm{pH}$ 7.0. Phosphate buffer $\mathrm{pH} 7.0$ was as an enzyme control blank. As positive control was used acarbose. Measurements were carried out triplicate. Percentage of inhibition was calculated by the equation as follow.

$\%$ Inhibition $=\left[1-\frac{[\text { Abs sample }- \text { Abs sample blank }]}{[\text { Abs control }- \text { Abs control blank }]}\right] \times 100 \%$

Determination of $\mathrm{IC}_{50}$ value was conducted with the similar procedure stated above using a range concentration of each sample from 250-2000 ppm. $\mathrm{IC}_{50}$ was derived from the regression curve by plotting each final concentration and \% inhibition of each sample using the Microsoft Excel program. Experiments were carried out triplicate. The type of inhibition was determined by measuring the percent inhibition of a range concentrations of the tested sample toward a series concentration substrate of p-nitrophenyl-alpha-D-glucopyranoside. A LineweaverBurk curve which stated the relationship between 1/V to 1/[S] (substrate concentration) was plotted and the type of inhibition was derived from the intersection between curves obtained.

\section{Total phenolic content determination}

Total phenolic compounds were determined using gallic acid as positive control based on the previous study ${ }^{12}$ with minor modifications. Briefly, twenty mg gallic acid was dissolved in $20 \mathrm{ml}$ of methanol and then diluted to make a serial concentration of working solutions $(25,50,100,150$ and $200 \mathrm{ppm}$ ) using methanol. Into the test tube, $200 \mu \mathrm{L}$ of each working solution was added with $750 \mu \mathrm{L}$ of Folin-Ciocalteau reagent, gently shaken until homogenous and then incubated at room temperature for 5 minutes. To the reaction, $750 \mu \mathrm{L}$ of $6 \%$ sodium carbonate solution was added, gently stirred and incubated in the same way for 90 minutes. Furthermore, absorbance was measured by UV-Vis spectrophotometer at $725 \mathrm{~nm}$. Methanol was used as a blank solution. Measurements were performed in triplicate. A calibration curve was made by extrapolating absorbance against to final concentration and the regression equation, $y=a x+b$, was calculated using the Microsoft Excel program. Total phenolic content of the tested samples were measured by dissolving 20 mg of each sample in $200 \mu \mathrm{L}$ dimetyl sulfoxide and then diluted with methanol until the final concentration $100 \mathrm{ppm}$ obtained. Each sample solution was carried out as positive control stated above. Total phenolic 
content was measured using the regression equation, $y=a x+b$, of gallic acid and stated as gallic acid equivalent (GAE). Percent of total phenolic content was calculated using this equation.

$\%$ Total phenolic content $=\left[\frac{G A E(\text { ppm })}{\text { final concentration }(\text { ppm })}\right] \times 100 \%$

\section{GC-MS analysis}

Ethyl acetate fractions of Ardisia humilis Vahl. leaves were analyzed by GC-MS technique for the detection of the active components present in the extract. GC analysis was conducted using a GC-MS (Agilent Technologies 7890) equipped with auto-injector and an HP Ultra 2 Capillary Column ((5\%-phenyl)-methylpolysiloxane) of $0.20 \mathrm{~mm}$ diameter, $30 \mathrm{~m}$ length, and $0.11 \mu \mathrm{m}$ film thickness. Ten $\mathrm{mg}$ of the semisolid sample were dissolved in $1 \mathrm{~mL}$ of methanol solvent, sonicated and centrifuged. The sample size of $5 \mu \mathrm{l}$ was injected through the injector. The inert gas helium was used as the carrier gas. Moreover, the MS chromatogram was taken at $70 \mathrm{eV}$ of ionization energy with $1.2 \mathrm{~mL} /$ minute column flow. The column mode used was constant flow. The initial temperature of the oven was $80^{\circ} \mathrm{C}$ hold for 0 minutes, rising at $3^{\circ} \mathrm{C} / \mathrm{min}$ to $150^{\circ} \mathrm{C}$ hold for 1 minute and finally rising $20^{\circ} \mathrm{C} /$ min to $280^{\circ} \mathrm{C}$ hold for 26 minutes. The relative percent amount of each component was expressed as a percentage with the peak area.

\section{Data analysis}

Data obtained from these experiments were presented as mean \pm SD Statistical analysis was conducted using the ANAVA (parametric data) or Kruskal-Wallis (non-parametric data) method and followed by the LSD (least square deference) for parametric data or Mann Whitney method non-parametric data to determine the further differences between samples. The analysis was carried out with SPSS 11 program at a 95\% confidence level $(\mathrm{p}=0.05)$. $\mathrm{P}$ value $<0.05$ was considered to be statistically significant.

\section{RESULTS}

\section{Sample preparation}

The experimental scheme and the sixth months of age Lampeni that planted in two different conditions were showed in Figures 1 and 2. The tested samples were prepared with the reflux method followed by liquid-liquid partition of crude extracts until some fractions obtained. The yield of all crude extracts and fractions of Lampeni was presented in Table 1. Crude extracts still contain various types of compounds ranging from non-polar to polar. To separate compounds based on their level of polarity a liquid-liquid partition using a type of solvent was carried out with different levels of polarity. The partition was began by separating the non-polar, semipolar and finally polar compounds using n-hexane, ethyl acetate, and water, respectively.

\section{Alpha-glucosidase inhibitory evaluation in vitro}

The inhibitory activities of each tested sample toward alpha glucosidase enzyme were presented in Figure 3. The value showed was an average of triplicate test results which conducted at $100 \mathrm{ppm}$ final concentration. The result displayed that ethyl acetate fraction (Fr. EtOAc) harvested at 4 and 6 months age demonstrated the highest activity. However, their activities were significantly different to positive control acarbose $(p<0.05)$. Both activity Fr. EtOAc of 4 and 6 months were almost the same $(\mathrm{p}=0.056)$.

Figure 3 demonstrated that the harvesting age influenced alphaglucosidase inhibition activity in which the older the plant age, the higher the inhibition activity was demonstrated. Sun exposure also
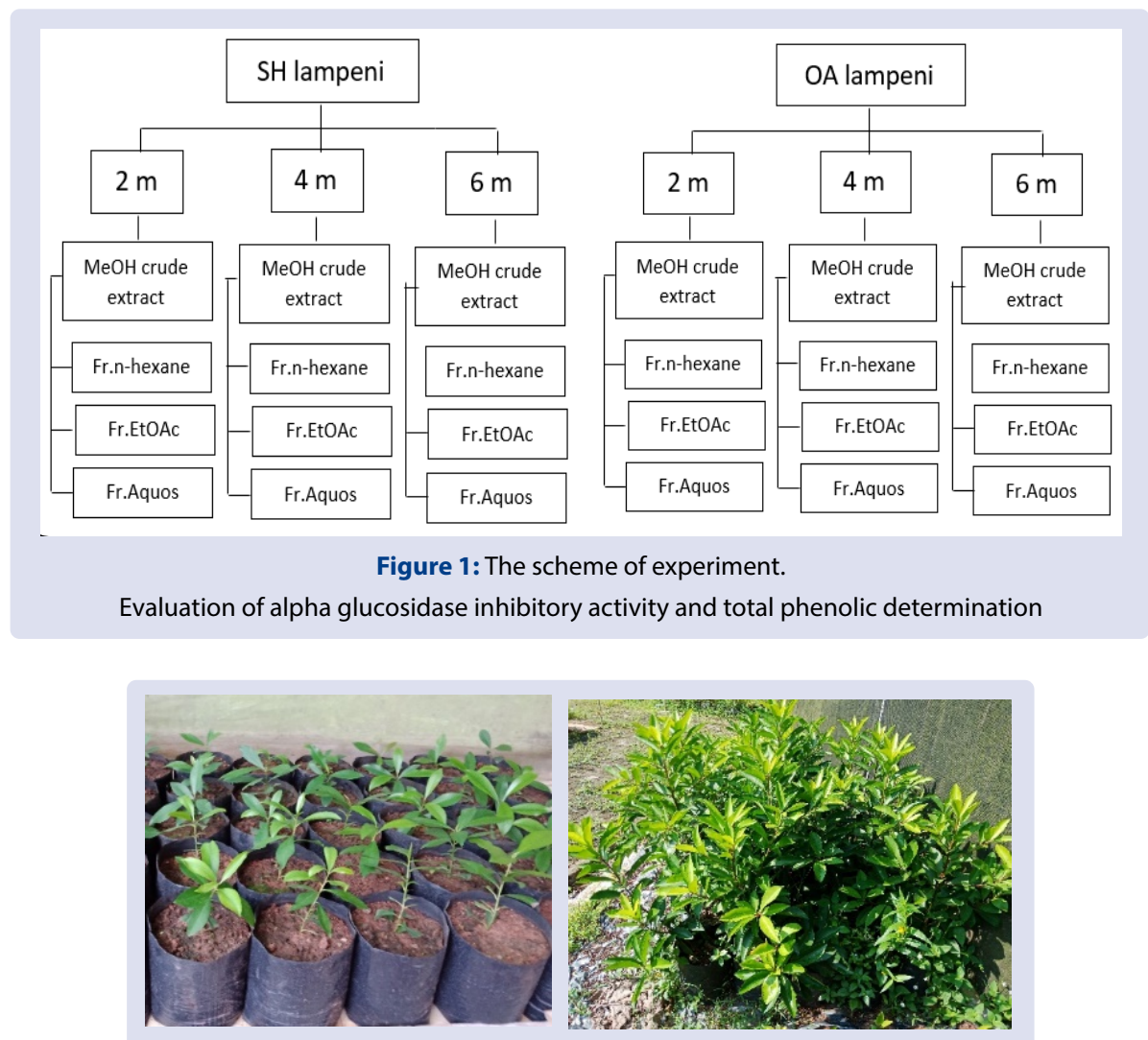

Figure 2: The sixth months of age Lampeni (Ardisia humilis Vahl.) at shedding house (left) and open air (right) location. 
Table 1: The yield of crude extract and fraction of each lampeni plant.

\begin{tabular}{|c|c|c|c|c|c|}
\hline \multirow{2}{*}{ Location } & \multirow{2}{*}{ The age of plant } & \multicolumn{4}{|c|}{ Extraction yield (g extract/ 100 g leaf powder) } \\
\hline & & Crude extract & Fr. n-hexane & Fr. EtOAc & Fr. Aquos \\
\hline \multirow{3}{*}{$\begin{array}{l}\text { Shedding } \\
\text { House }\end{array}$} & $2 \mathrm{~m}$ & 10.38 & 1.42 & 0.66 & 9.34 \\
\hline & $4 \mathrm{~m}$ & 15.13 & 1.30 & 1.58 & 12.63 \\
\hline & $6 \mathrm{~m}$ & 9.71 & 1.93 & 1.54 & 7.46 \\
\hline \multirow{3}{*}{ Open air } & $2 \mathrm{~m}$ & 13.48 & 1.14 & 1.24 & 15.38 \\
\hline & $4 \mathrm{~m}$ & 20.67 & 1.35 & 0.88 & 14.34 \\
\hline & $6 \mathrm{~m}$ & 18.47 & 0.48 & 1.27 & 14.29 \\
\hline
\end{tabular}

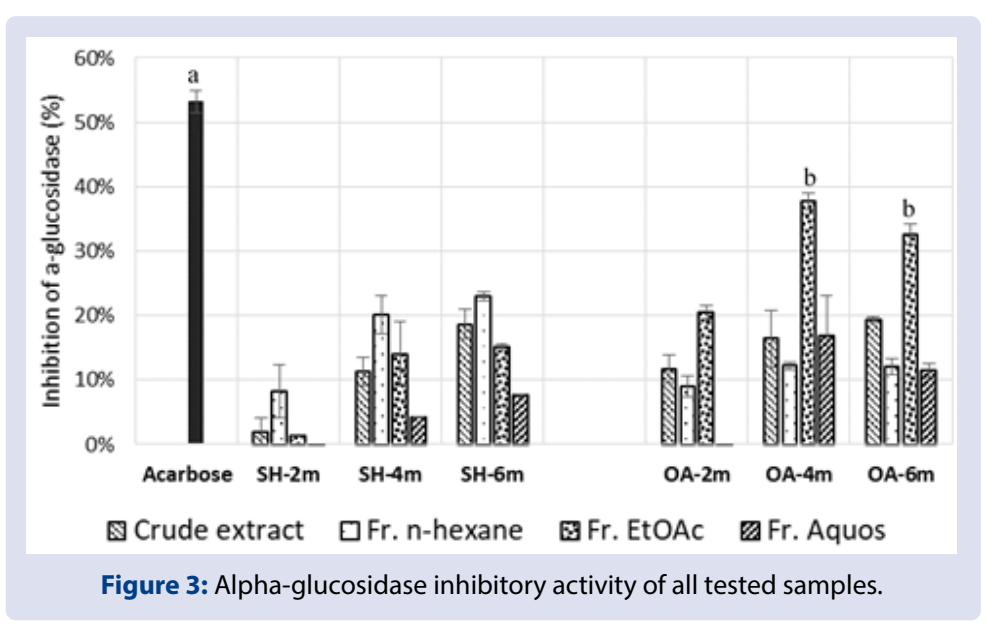

contributed to the inhibitory activity. Plants which placed in the open-air provided better activities than those one maintained in shedding house. It was an interesting phenomenon that the activity of each fraction from the two planting conditions showed a different pattern. On the plants that cultivated in shedding house, the $n$-hexane fraction showed higher activity than the other two fractions. While on plant cultivated direct to sun exposure, the highest activity was shown in EtOAc fractions, especially from 4 and 6 months harvested leaves. The inhibitory strength of both EtOAc fraction was significantly higher than the other fractions. However, when they were compared to control acarbose, it was still significantly lower $(\mathrm{p}<0.05)$. The $\mathrm{IC}_{50}$ values for the two most active fraction were presented in Table 2.

Table 2 showed that the EtOAc fraction provided a higher resistance than the other fractions, especially for plants harvested at the age of 4 and 6 months. $\mathrm{IC}_{50}$ values of both EtOAc fractions were $93.50 \mathrm{ppm}(\mathrm{Fr}$ EtOAc OA-4m) and 98.13 ppm (Fr EtOAc OA-6m), respectively, and those both values were not statistically significantly different $(p>0.05)$. The inhibition type of the two most active samples (Fr EtOAc OA-4m and Fr EtOAc OA-6m) was presented in Figure 4.

Figure 4 displayed the kinetic study toward alpha glucosidase inhibition of 2 samples that had the highest activity, in which there was a speed decreasing when the inhibitor (samples) concentrations were increased. It also showed that the $\mathrm{Km}$ value remained the same even though the inhibitor concentrations were added. According to the inhibition type criteria, the curve as Figure 4 was non-competitive category. $\mathrm{Km}$ is the Michaelis Menten constant which expresses the affinity of the enzyme to the substrate. The value of $\mathrm{Km}$ is shown by the intersection between the curve and the $\mathrm{x}$-axis. ${ }^{13}$ The each Km value of the two EtOAc fractions were almost the same at the range between 0.3-0.4. This means that the possibility of chemical compounds composition that provided alphaglucosidase inhibition from both fractions originating from different the age of harvest ages was almost similar. In non-competitive type inhibitions, inhibitors (chemical compounds in the fraction) bound to either E (enzyme) or ES (enzyme-substrate) complex and produced EI (enzyme-inhibitor) and ESI (enzyme-substrate-inhibitor) complexes. The compounds contained in the Fr.EtOAc, in these studies, may not bind at the same side as the substrate, this was possibility due to the structure of the compounds might possess no resemblance to the substrate structure. Complexes that are formed either EI or ESI cause the changing of enzyme conformation and then the catalytic reaction can not work perfectly. ${ }^{13,14}$

\section{Total phenolic content determination}

The results of total phenolic levels measurement were shown in Figure 5. Total phenolic content was the average from 3 times measurements expressed as mg galic acid equivalent (GAE) /final concentration $\mathrm{x}$ $100 \%$. Total phenolic was determined using Folin-Ciocalteau reagent spectrophotometerically at $725 \mathrm{~nm}$.

Figure 5 demonstrated that the levels of total phenolic compounds in methanol crude extract did not differ significantly between the age of planting (2,4, and 6 months) and between planting conditions (openair and shedding house). However, in the fractioned samples, EtOAc fraction of each planting condition showed the highest total phenol compound level compared to the other fractions, especially in the leaves that harvested at the age of 4-OA and 6-OA months. Statistically, all of EtOAc fractions did not differ significantly ( $\mathrm{p}=0.118)$.

\section{GC-MS analysis}

In this study, all of EtOAc fractions of Ardisia humilis Vahl. leaves planted in the open area $(\mathrm{OA})$ and shedding house $(\mathrm{SH})$ conditions were analyzed using GC-MS (the spectra of each EtOAc fraction were presented in Figure 6). GC-MS analysis was conducted with the HP ultra 2 capillary that had non-polar properties. Based on the chromatogram, it showed that the most major peaks chromatogram appeared in the middle area. It indicated that the majority of the dominant compounds contained in Fr.EtOAc of Lampeni leaves were semi-polar. After being matched with the database, pyrogallol (38.52 \% with RT 17.8, Figure 7) 
Table 2: $\mathrm{IC}_{50}$ value of tested samples.

\begin{tabular}{cccccc}
\hline $\begin{array}{c}\text { Final concentration } \\
(\mathrm{ppm})\end{array}$ & $\begin{array}{c}\text { Fr. EtOAc OA-4m } \\
\text { Inhibition } \\
(\%)\end{array}$ & $\begin{array}{c}\mathrm{IC}_{50} \\
(\mathrm{ppm})\end{array}$ & $\begin{array}{c}\text { Final concentration } \\
(\mathrm{ppm})\end{array}$ & $\begin{array}{c}\text { Fr. EtOAc OA-6m } \\
\text { Inhibition } \\
(\%)\end{array}$ & $\mathrm{IC}_{50}(\mathrm{ppm})$ \\
\hline 186.67 & $97.4 \%$ & & 186.67 & $99.6 \%$ & \\
140.00 & $71.1 \%$ & & 140.00 & $74.3 \%$ & \\
93.33 & $39.3 \%$ & 93.50 & 93.33 & $37.2 \%$ & 98.13 \\
46.67 & $31.1 \%$ & & 46.67 & $28.4 \%$ & \\
23.33 & $21.7 \%$ & & 23.33 & $9.4 \%$ & \\
\hline
\end{tabular}

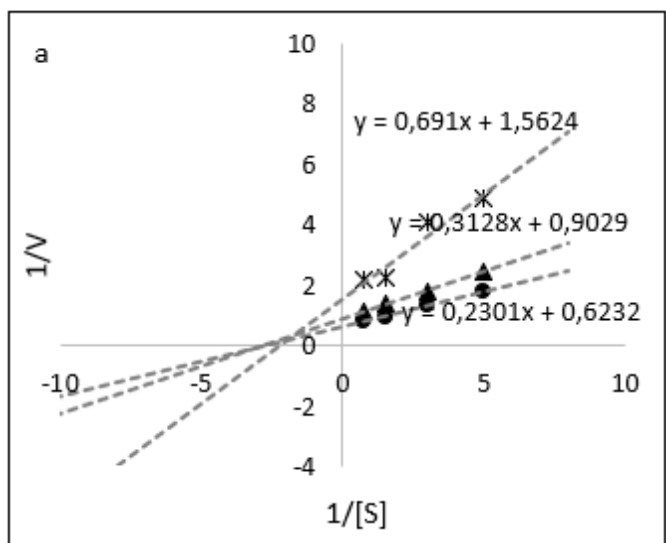

- 0 ppm $\Delta 500 \mathrm{ppm}$ * $1500 \mathrm{ppm}$

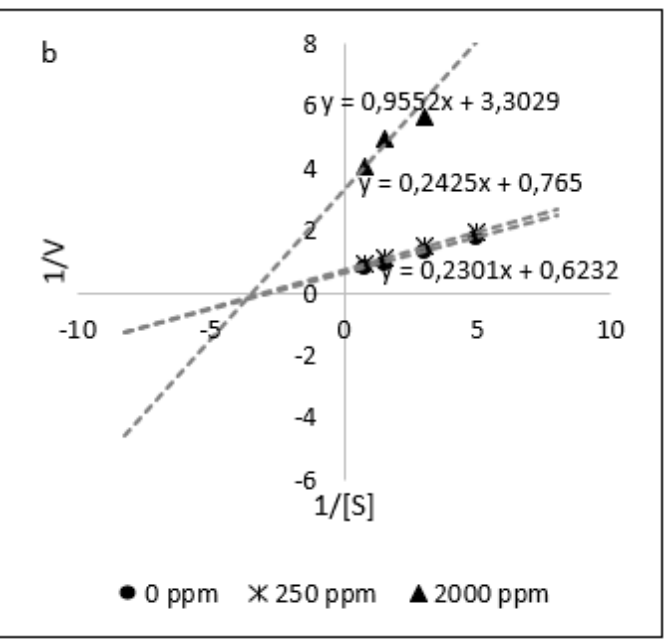

Figure 4: Lineweaver-Burk plot curve (a) Fr. EtOAc OA-4m (b) Fr. EtOAc OA-6m.

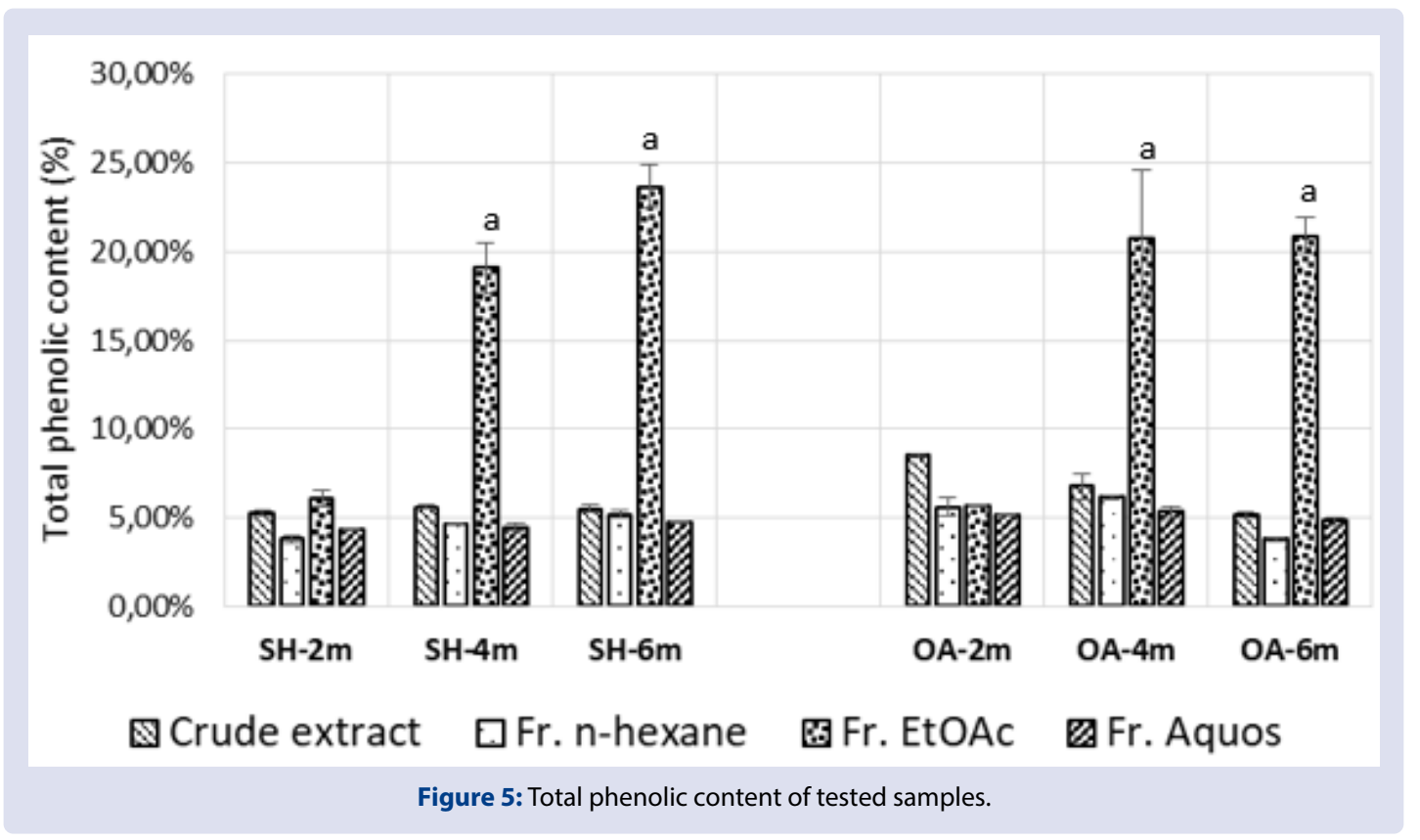




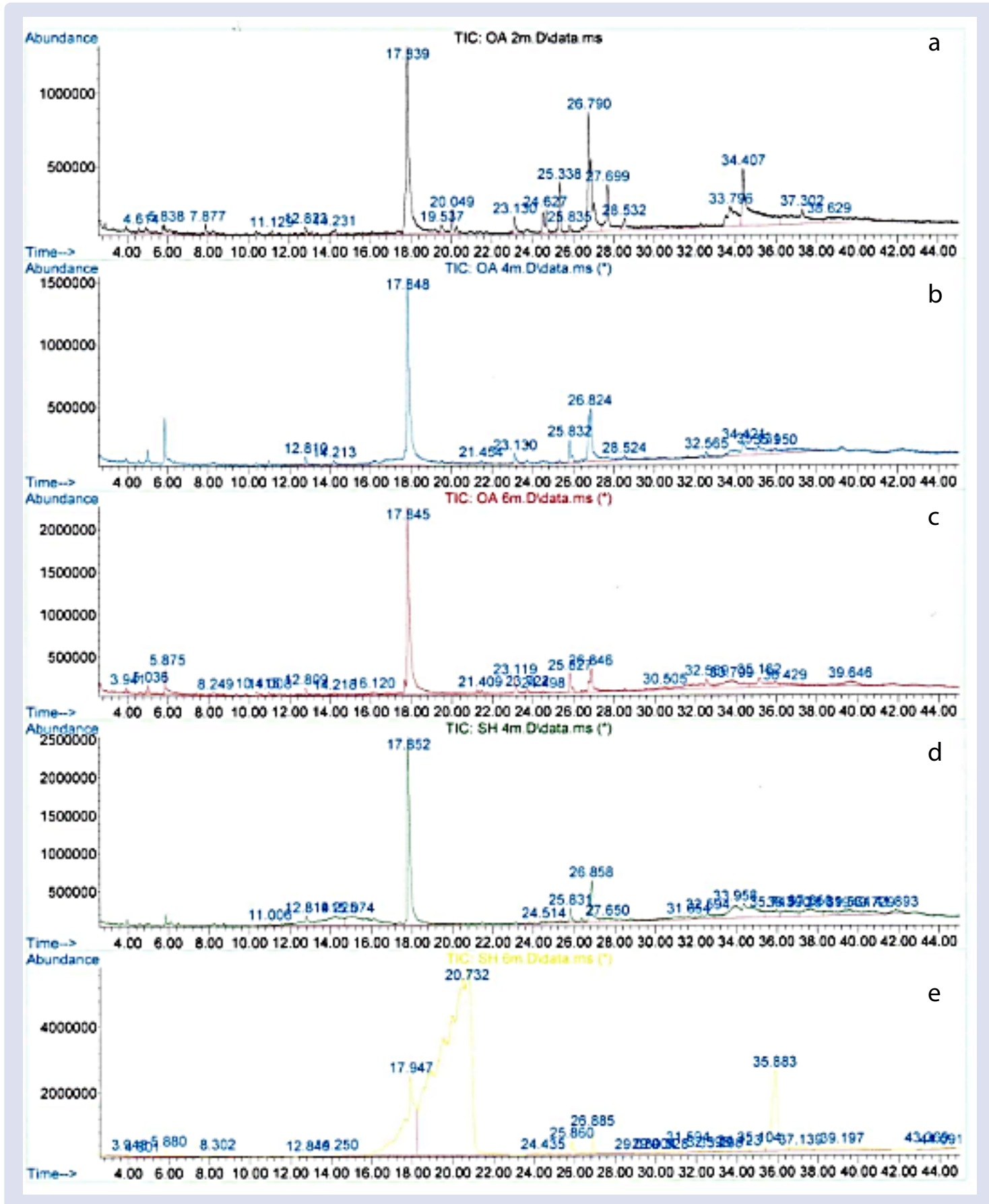

Figure 6: GC-MS chromatogram of ethyl acetate fraction of Lampeni leaves. (a) OA-2m; (b) OA-4m; (c) OA-6m; (d) SH-4m; (e) $\mathrm{SH}-6 \mathrm{~m}$.

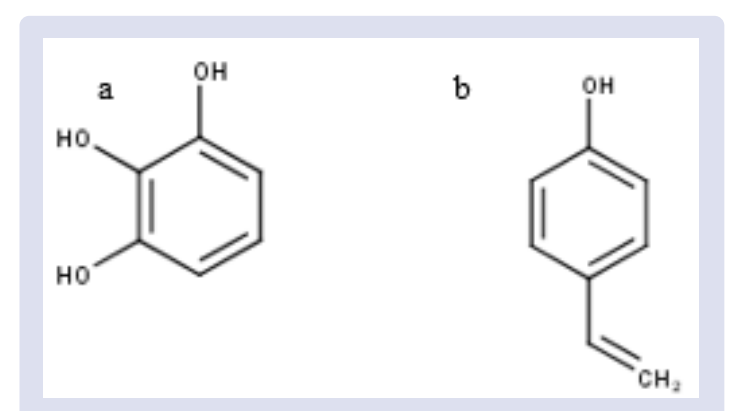

Figure 7: Structure of pyrogallol (a) and 4-vinylphenol (b). 
could be categorized as the major compound in which the compound appeared with the biggest total area in all tested fraction. Additionally, some peaks of the OA-4m and OA-6m fraction with RT 4 and 8 minutes appeared more abundance. One of the most apparent peak of both fractions was 4 -vinylphenol (4.13\% with RT 5.876) (Figure 7).

\section{DISCUSSION}

Glucose in the body can be categorized into two, namely exogenous glucose (derived from food intake) and endogenous glucose, which derived dominantly from the liver with glycogenolysis (conversion of glycogen to glucose) and gluconeogenesis (glucose formation), which about $\sim 15 \%$ is produced by the kidneys. The imbalance of production and usage of glucose could be the cause of hyperglycemia. ${ }^{15}$ Intake of starch-rich foods (a chain glucose molecule) is one of the leading causes of the postprandial glucose increase. Starch hydrolysis process to produce glucose monomer compounds which can be absorbed from gastrointestinal tract involves various enzymes ranging from ptyalin in the oral cavity to hydrolytic enzymes such as alpha-amylase and alphaglucosidase. ${ }^{16}$ These enzymes that contributed to hydrolyzing amylum to be oligo and monosaccharide form are called amylolytic enzymes. ${ }^{17}$ Monosaccharides absorbed will be transported through the portal vessels to the liver. The efforts to inhibit these enzymes will be beneficial in suppressing postprandial glucose which plays a main role in DM type 2 treatment. ${ }^{18}$ Postprandial hyperglycemia is an elevation of blood glucose level after a meal. There are some evidences that the chronically postprandial hyperglycemia associated with macro and microvascular complication through a complex oxidative stress generation, vascular inflammation and platelet activation pathways. ${ }^{19}$

Some plants demonstrated the inhibitory activity in the starch metabolizing enzyme. ${ }^{3}$ This activity was caused by the content of chemical compounds such as polyphenol or phenolic compounds in which the concentrations were influenced by several agronomic factors such as the place to grow, the way and age of harvest, and post-harvest processing. ${ }^{10}$ The inhibitory alpha-glucosidase activity of these Ardisia humilis extracts shown in this study were in accordance with the previous studies. It had been reported previously that the alpha-amyrin compound isolated from $70 \%$ methanolic extract of Ardisia elliptica leaves exhibited activity in decreasing blood glucose level. ${ }^{20}$ The other research found that alpha-amyrin decreased blood glucose about $17 \%$ at $24 \mathrm{~h}$ after sucrose induction in STZ-induced diabetic rat that induced by sucrose at dose $100 \mathrm{mg} / \mathrm{kg}$ bw per oral. ${ }^{6}$

The agricultural study states that the quality and quantity of compounds in the plant-derived extract are significantly affected by many factors such as climate, seasons of the year, phenological stage, genetic load, temperature, altitude, cultivation conditions and humidity. ${ }^{21}$ The secondary metabolite compounds determine the strength and type of biological activity of a natural product. The research presented that the levels of phenolic compounds were influenced by planting conditions and the age of harvest. The leaves harvested at the age of 2 months were not fully grown, so the secondary metabolites were not completely produced. It gave the consequence that the inhibition strength was the lowest due to the total phenol content too low. The older the plant, the stronger the alpha glucosidase inhibitory activity was produced. The inhibition strength of alpha-glucosidase enzyme was proportionate with the total phenolic content of the extract in which it was influenced by some factors such as the age of the plant and the method of planting. This result was in accordance with the previous study that conducted in Yerba mate ${ }^{8}$ in which the antioxidant activity and total phenolic content were significantly affected by leaves age. The other study ${ }^{22}$ also demonstrated that there was a correlation between the phenolic compound level and antidiabetic activity such as in Sansevieria cylindrica extract, a plant that traditionally used for the treatment of various ailments in African countries. Phenolic compounds contained in plants had been recognized to have some pharmacological activities, such as antimicrobial, antioxidant, antitumor, and antidiabetic activities. ${ }^{23}$ This result was supported by GC-MS analysis, in which after being matched with database, it showed that the phenolic compound pyrogallol was found as the most dominant compound in all tested fractions. Additionally, there were several compounds found only in ethyl acetate fractions (OA-4m and OA-6m fraction) with high inhibitory activity, one of which was 4 -vinyl phenol. The presence of this compound may cause both the OA-4m and OA-6m EtOAc fractions demonstrated the highest alpha-glucosidase inhibitory activity besides others which previously reported.

\section{CONCLUSION}

The effect of some agronomic variable (the light intensity and the age of harvesting) and extract preparation of Ardisia humilis Vahl. (Lampeni) toward the inhibitory activity of alpha-glucosidase enzyme and polyphenol content had been investigated. The results showed that the plant cultivated under direct sun exposure harvested at the age of 4-6 months and prepared as ethyl acetate fraction gave the highest alpha-glucosidase inhibition activity although there was no positive correlation between the strength of inhibition and total phenolic content.

\section{ACKNOWLEDGEMENT}

This work was supported by Centre for Pharmaceutical and Medical Technology, Agency for the Assessment and Application of Technology (BPPT). The authors were deeply thankful to Rusmanto and Ernawati Simanjutak who had assisted in the technical laboratory.

\section{AUTHORS CONTRIBUTION}

Sri Ningsih (SN). Fifit Juniarti (FJ). Idah Rosidah (IR). Syofi Rosmalawati (SR). Agung Eru Wibowo (AEW). Adam Arditya Fajriawan (AAF). Kurnia Agustini (KA). Wahono Sumaryono (WS). Erliana Sasikirana (ES). SN, AEW, and WS conceived and planned the experiments. SN, FJ, IR, SR, KA, ES carried out the experiments. SN and ES analyzed data. SN, ES and WS contributed to the interpretation of the results. SN and AAF prepared, corrected and submited the manuscript.

\section{CONFLICTS OF INTEREST}

No potential conflicts of interest were reported by the authors.

\section{REFERENCES}

1. Gerich J. Pathogenesis and management of postprandial hyperglycemia: Role of incretin-based therapies. Int J Gen Med. 2013;6:877-95.

2. Lakshmi T, Ramasamy R, Thirumalaikumaran R. Preliminary phytochemical analysis and In vitro antioxidant, FTIR spectroscopy, anti-diabetic activity of Acacia catechu ethanolic seed extract. Pharmacogn J. 2015;7(6):356-62.

3. Chaudhury A, Duvoor C, Reddy Dendi VS, Kraleti S, Chada A, Ravilla R, et al. Clinical review of antidiabetic drugs: Implications for type 2 diabetes mellitus management. Front Endocrinol (Lausanne). 2017;8(6):1-12.

4. Khatun A, Rahman M, Kabir S, Akter MN Chowdhury SA Phytochemical and pharmacological properties of methanolic extract of ardisia humilis vahl. (myrsinaceae). Int J Res Ayurveda Pharm. 2013;4(1):38-41.

5. Santoso P. Uji aktivitas antiplatelet ekstrak daun lempeni (Ardisia humilis Vahl) pada mencit. 1(1):9-14

6. Narender $T$, Khaliq $T$, Singh AB, Joshi MD, Mishra P, Chaturvedi JP, et al Synthesis of $\alpha$-amyrin derivatives and their in vivo antihyperglycemic activity. Eur J Med Chem. 2009;44(3):1215-22.

7. Ching J, Chua TK, Chin LC, Lau AJ, Pang YK, Jaya JM, et al. $\beta$-amyrin from Ardisia elliptica Thunb. Is more potent than aspirin in inhibiting collagen-induced platelet aggregation. Indian J Exp Biol. 2010;48(3):275-9.

8. Blum-Silva $\mathrm{CH}$, Chaves VC, Schenkel EP, Coelho GC Reginatto FH. The influence of leaf age on methylxanthines, total phenolic content, and free radical scavenging capacity of ilex paraguariensis aqueous extracts. Brazilian $J$ Pharmacogn. 2015;25(1):1-6. 
9. Aquino Esmelindro Â, Santos Girardi J Dos, Mossi A, Assis Jacques R, Dariva C. Influence of Agronomic Variables on the Composition of Mate Tea Leaves (Ilex paraguariensis) Extracts Obtained from $\mathrm{CO}_{2}$ Extraction at $30{ }^{\circ} \mathrm{C}$ and 175 bar. J Agric Food Chem. 2004;52(7):1990-5.

10. Gobbo-Neto L, Lopes NP. Plantas medicinais: Fatores de influência no conteúdo de metabólitos secundários. Quim Nova. 2007;30(2):374-81.

11. Dewi RT, Iskandar YM, Hanafi M, Kardono LBS, Angelina M, Dewijanti ID, et al. Inhibitory effect of Koji Aspergillus terreus on $\alpha$-glucosidase activity and postprandial hyperglycemia. Vol. 10, Pakistan Journal of Biological Sciences. 2007:3131-5

12. Abd Ghafar MF, Prasad KN, Weng KKIA. Flavonoid, hesperidine, total phenolic contents and antioxidant activities from Citrus species. African J Biotechnol 2010;9(3):327-30

13. Saboury AA. Enzyme inhibition and activation: A general theory. J Iran Chem Soc. 2009;6(2):219-29.

14. Fange D, Lovmar M, Pavlov MY, Ehrenberg M. Identification of enzyme inhibitory mechanisms from steady-state kinetics. Biochimie. 2011;93(9):16239.

15. Triplitt CL. Examining the mechanisms of glucose regulation. Am J Manag Care. 2012;18(1 Suppl):4-10

16. Iman M, Moallem SA, Barahoyee A. Effect of apple cider Vinegar on blood glucose level in diabetic mice. Pharm Sci. 2015;20(4):163-8.
17. Horváthová V, Janeček Š, Šturdík E. Amylolytic enzymes: Molecular aspects of their properties. Gen Physiol Biophys. 2001;20(1):7-32.

18. Moritoh Y, Takeuchi K, Hazama M. Voglibose, an alpha-glucosidase inhibitor to increase active glucagon-like peptide-1 levels. Mol Cell Pharmacol. 2009;1(4):188-92.

19. Yamagishi S, Nakamura K, Takeuchi M. Inhibition of postprandial hyperglycemia by acarbose is a promising therapeutic strategy for the treatment of patients with the metabolic syndrome. Med Hypotheses. 2005;65(1):152-4.

20. J. Ching. Chemical and Pharmacological Studies of Ardisia Elliptica: Antiplatelet Anticoagulant Activities and Multivariate Data Analysis For Drug Discovery. Ph.D. Dissertation. Dept. Pharmacy, National University of Singapore, Singapore, 2011.

21. Inácio MC, Paz TA, Bertoni BW, Pereira AMS. Efeito de fatores ambientais fenológicos sobre a atividade antimicrobiana de raízes de Cochlospermum regium (Schrank) Iv. Acta Sci - Agron. 2016;38(4):467-73.

22. Minatel IO, Borges CV, Alonso HGG, Ferreira MI, Chen CYO, Lima GPP. Phenolic Compounds: Functional Properties, Impact of Processing and Bioavailability. Intechopen. 2017. Available from: https://www.intechopen.com/ books/phenolic-compounds-biological-activity/phenolic-compounds-functionalproperties-impact-of-processing-and-bioavailability

23. Tanveer A, Devendra Singh N, Faheem Khan M. Phytochemical Analysis, Total Phenolic Content, Antioxidant and Antidiabetic Activity of Sansevieria cylindrica Leaves Extract. Herb Med Open Access. 2017;03(02):1-6.

\section{GRAPHICAL ABSTRACT}

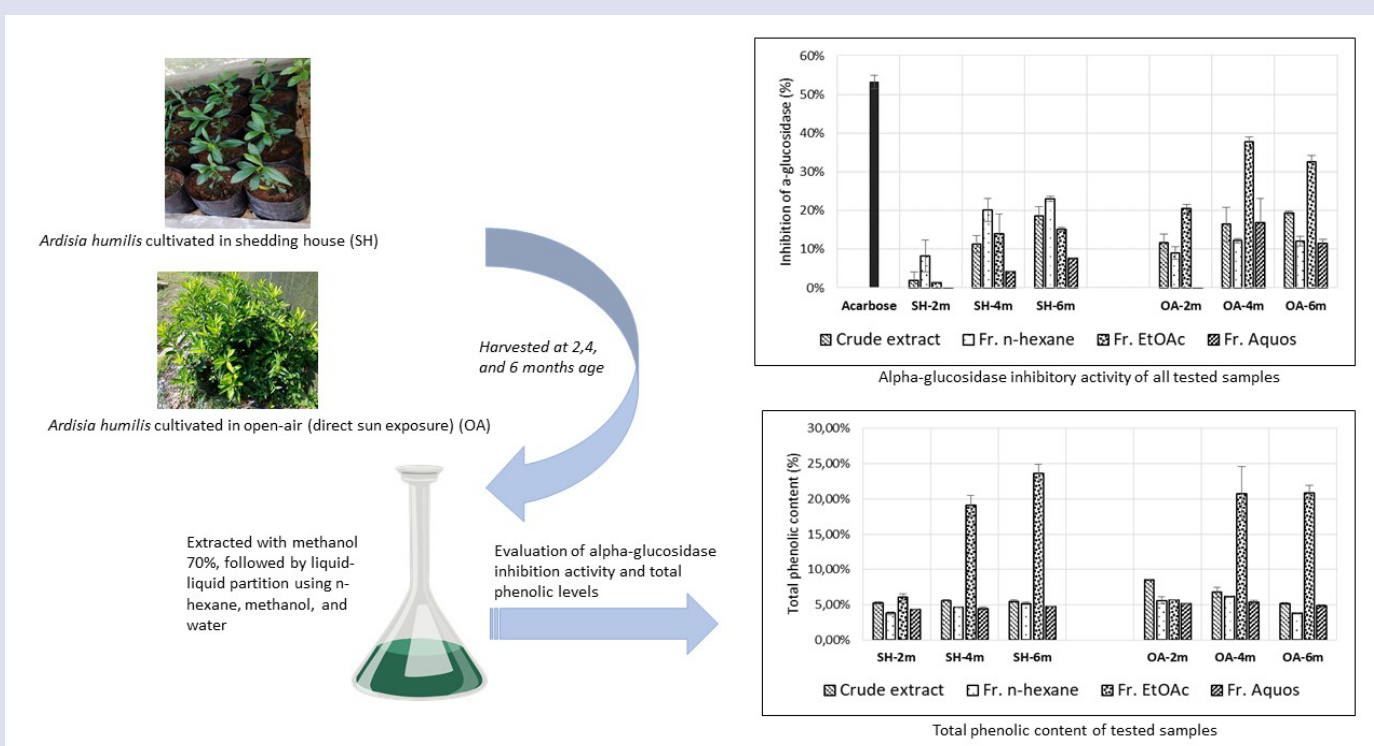

\section{ABOUT AUTHORS}

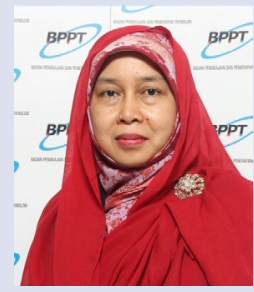

Sri Ningsih was born in Surakarta, Central Java, Indonesia on February 22, 1970. She graduated from undergraduate program of Pharmacy Department, Bandung Institute of Technology, Indonesia (1993), postgraduate program of Department of Chemistry, Indonesia University (2001) and doctoral program of Biomedical Sciences, Faculty of Medicine, Indonesia University (2015). She is as researcher at The Center for Pharmaceutical and Medical Technology, Agency for the Assessment and Application of Technology until now. Her research area includes the experimental pharmacology of natural product.

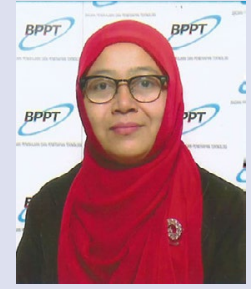

Fifit Juniarti was born in Moscow, Russia on June 17, 1972. She graduated as Bachelor of Science (Honours) from the Faculty of Health and Medical Science, The University of Adelaide in 1996 and currently working as researcher in The Center for Pharmaceutical and Medical Technology, Agency for the Assesment and Application of Technology. Her research areas include bioprospecting of medicinal plants and molecular biology in health 


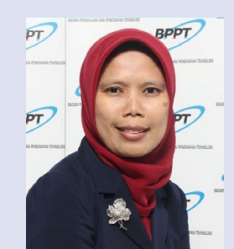

Idah Rosidah was born in Indramayu, West Java, Indonesia on October 10, 1975. She was undergraduate from Department of Pharmacy, University of Pancasila, Indonesia (1999) and postgraduate at Department of Pharmacy, University of Indonesia (2010). She is as researcher at The Center for Pharmaceutical and Medical Technology, Agency for the Assessment and Application of Technology until now. Her research area includes pharmacy and experimental pharmacology of natural products.

Adam Arditya Fajriawan was born in Klaten, Central Java, Indonesia on July 20, 1995. He graduated from undergraduate program, Faculty of Pharmacy, Universitas Indonesia in 2017 and now working as researcher in The Center for Pharmaceutical and Medical Technology, Agency for the Assesment and Application of Technology. His research areas include in vitro bioassay, cell culture, and biological activity study of natural products.

Kurnia Agustini was born in Jakarta, Indonesia on August 13, 1970. She graduated from undergraduate program of Pharmacy Department, University of Indonesia at 1996 and finished her Apothecary Professional Program at 1997. She is working as researcher at Agency for the Assessment and Application of Technology (BPPT) since 1997. She finished her Master program at of Pharmacy Department, University of Indonesia at 2004 and her PhD program at Medical Faculty, University of Indonesia at 2012. As researcher in Centre for Pharmaceutical and Medical Technology BPPT, her research area mostly in natural product pharmacology, phytochemistry, toxicology, cell-based assay and clinical assay.

Agung Eru Wibowo was born in Bantul, Indonesia on 28 Februari 1968. He graduated from undergraduate program of Faculty of Pharmacy, Gadjah Mada University at 1993 and finished her Apothecary Professional Program at 1994. He finished his Master program at of Chemistry Department, University of Indonesia at 2003 and her PhD program at Medical Faculty, University of Indonesia at 2011. As researcher in Centre for Pharmaceutical and Medical Technology BPPT, his research area mostly in natural product chemical compound, phytochemistry, toxicology, cell-based assay and clinical assay.

Syofi Rosmalawati was born in Bandung, West Java, Indonesia on January 12, 1969. She was undergraduate from Department of Biology, Padjadjaran University, Indonesia (1994), Postgraduate from Department of Bioregulation and Biointeraction, Tokyo University, Japan (2005). She is as researcher at Laboratory of Biotechnology, Agency for the Assessment and Application Technology until now. Her research filed is plant disease control.

Erliana Sasikirana was born in Yogyakarta, September 24, 1996. She was undergraduate (2018) and post graduate (2019) in the Departement of Pharmacy, Pancasila University. She is working as a reponsible pharmacist at the private medical distributor in Jakarta, Indonesia until now.

Wahono Sumaryono has completed his Ph.D (Dr.rer.nat) in July 1990, from Institute for Pharmaceutical Biology - Technical University "Carolo - Wilhelmina", Braunschweig-Fed.Rep.of Germany- Now he is Professor in Natural Product Chemistry at Faculty of Pharmacy Universitas Pancasila Jakarta, since 2007. He has published 18 International Scopus journals in the field of Natural Products and related subjects. His contribution for this publication was as supervisor of the experimental methodology.

Cite this article: Ningsih S, Juniarti F, Rosidah I, Fajriawan AA, Agustini K, Rosmalawati S, et al. Study of the Effect of Lampeni (Ardisia humilis Vahl.) Planting Condition toward the Alpha-glucosidase Inhibition Activity In vitro. Pharmacog J. 2020;12(2):377-85. 